\title{
Effect of Grafting Dates on Success and Growth of Kumquat (Fortunella japonica Swingle) Sapling
}

\author{
Nirajan Bhandari ${ }^{1 *}$ and Chiranjivi Regmi ${ }^{2}$ \\ ${ }^{1}$ Institute of Agriculture and Animal Science, Gauradaha, Jhapa \\ ${ }^{2}$ Nepal Academy of Science and Technology (NAST) \\ "Corresponding Author's Email: iaasnirajan@gmail.com \\ *Orcid ID: http://orcid.org/0000-0002-4774-9604
}

Received on: 30 September 2020, Revised on16 April 2021, Accepted on: 17 April 2021

\begin{abstract}
An experiment was carried out to study the effect of grafting dates on the success and growth of kumquat sapling during 2017-18 at Banepa, Kavre to standardize suitable grafting time. The experiment was conducted in a single factor completely randomized design with five treatments and three replications. The treatments consisted of five grafting dates viz., $25^{\text {th }}$ November, $10^{\text {th }}$ December, $25^{\text {th }}$ December, $10^{\text {th }}$ January and $25^{\text {th }}$ January. Scion collected from the mother plant of kumquat was grafted onto two years old trifoliate orange rootstock by side veneer method at 15 days intervals under screen house. The data were recorded at every 30 days interval and found a significant effect of grafting dates on most of the economically important parameters such as graft success percent, the mortality of sprouted grafts, sapling height, number of leaves per sapling and leaf area. The result revealed that $100 \%$ graft success was observed on the grafts prepared in January. The highest mortality $(13.68 \pm 0.58 \%)$ was reported on $25^{\text {th }}$ November grafted sapling. The sapling height $(39.68 \pm 3.68 \mathrm{~cm})$, number of leaves per sapling $(23.12 \pm 3.43)$ and leaf area $\left(16.34 \pm 1.05 \mathrm{~cm}^{2}\right)$ were found superior for $10^{\text {th }}$ January grafted sapling while the number of primary and secondary branches per sapling were found non-significant for all grafting dates. Therefore, the study revealed that $10^{\text {th }}$ January was the most suitable time for grafting of kumquat under Kavre, Nepal conditions.
\end{abstract}

Keywords: Days after grafting, Graft success, Kumquat, Propagation, Temperature

\section{Introduction:}

Fortunella japonica is also known as "Marumi" or "Round Kumquat" ('Muntala' in Nepali) is an evergreen shrub or small tree having orange colored round shaped fruits with thick fleshy sweet flavored skin and a distinctly sour center (Palma \& D'Aquino, 2018; Gmitter et al., 2007). The fruits are generally eaten as a dessert or preserved in syrups and marmalades. Kumquat is well suited in the sub-tropical region but can tolerate a temperature below $13^{\circ} \mathrm{C}$. It can be grown in a climate where temperature does not fall below $4^{\circ} \mathrm{C}$ but require warm conditions for ripening and sweeter taste (Hussein \& Ibrahim, 2020). Kumquat is not commercially cultivated in Nepal so far but farmers and most of the citrus lovers have grown one to few plants of kumquat in their kitchen gardens or rooftops for its attractive and highly delicious fruits. Kumquat is an excellent source of nutrients and phytochemicals vitamins, carotenoids, flavonoids and terpenoids with an abundance of antioxidants (Palma \& D'Aquino, 2018; Nouri \& Shafaghatlonbar, 2016) and high 
medicinal value which helps to improve the appearance of the skin (Satyal et al., 2012). Currently, kumquat has no specified market but it has a high potentiality of commercialization in near future due to its high market value and increasing demand on hotels and restaurants, party palace and social functions and gatherings as a dessert fruit.

Generally, it has been found that the nurseries have propagated kumquat by seed. However, it can be propagated through grafting, budding and micropropagation also.There is no research work has been conducted on the commercial multiplication and propagation of kumquat in Nepal. Being a related genus of citrus, it can be also commercially propagated through grafting. The trifoliate orange (Poncirus trifoliata) has been found best rootstock for the grafting of kumquat (Morton, 1987). Additionally, the success and subsequent growth of grafted plants depend on many factors like prevailing environmental conditions, variety, method of grafting and selection of scion and rootstock (Hartmann et al., 2002). The success or failure of grafting is primarily determined by prevailing weather conditions like temperature, relative humidity, light and rainfall which have a direct influence on the graft union formation and growth of grafted sapling (Singh \& Singh, 2006). So, one of the important aspects of successful grafting is the selection of appropriate season and time which is conducive to rapid graft healing and subsequently the formation of the graft union. A study conducted in different parts of Nepal revealed that the optimum time for grafting of citrus species is November to January for the mid-hills of Nepal (Poon, 1999; Gautam et al., 2001; Chalise et al., 2013). However, commercial propagation of kumquat through grafting and the selection of suitable grafting time remains a major consideration for graft success and subsequent growth of grafted sapling in the Nepalese context. Similarly, like citrus, the performance of kumquat scion on trifoliate orange root stock also needs to be evaluated. So, the present study was undertaken to investigate the success and growth of kumquat grafts with respect to different grafting dates under screen house conditions in central mid-hills of Nepal.

\section{Materials and methods}

The present investigation was carried out at Banepa, Kavre during the year 2017-2018 to find out the most suitable date for graft take success in kumquat. The site was located on $27.6332^{\circ} \mathrm{N}$ and $85.5277^{\circ} \mathrm{E}$ with an elevation of 1500 meter above sea level. The experiment was conducted in the screen house.

\section{Design of experiment}

The experiment was laid out in a single factor Completely Randomized Design (CRD) with five treatments and three replications. The treatments consisted of five grafting dates i.e. $25^{\text {th }}$ November, $10^{\text {th }}$ December, $25^{\text {th }}$ December, $10^{\text {th }}$ January and $25^{\text {th }}$ January. There were a total of 15 experimental plots having 8 grafted plants per plot.

\section{Selection and preparation of scion}

The scion shoots were collected from the healthy, matured and well-grown mother plants of kumquat which were maintained on the mother block of the research site. About 7-8-month-old scion shoots were selected from the terminal shoots of current season growth. Immediately after the separation of bud sticks from mother trees, they were wrapped in a moist cloth and carried out to the site of grafting. The scion shoots werethen separated into a number of scions containing two active buds. The average length of scion was 4.2 $\mathrm{cm}$ and the diameter was $0.61 \mathrm{~cm}$.

\section{Rootstock production}

The trifoliate orangewas used as a rootstock. The seeds of trifoliate orange were sown in the well-prepared nursery bed containing sand, soil and compost in the ratio of 1:1:1 which was maintained in the screen house in December. About 6-month-old rootstocks having $8-10 \mathrm{~cm}$ height and 6-8 leaves were transplanted in the polybags containing forest soil: field soil: FYM: sand (1:1:1:1). The rootstocks were then allowed to grow for 1.5 years until all the rootstocks become pencil size thick and height of $25 \mathrm{~cm}$. Weeding, irrigation and fertilization were performed regularly for the entire duration. The average diameter of rootstock was 0.72 $\mathrm{cm}$ at the time of grafting.

\section{Grafting technique}

A side veneer method was practiced at 15 days intervals for grafting. A slanting cut of $2 \mathrm{~cm}$ was made on the scion and then another very short cut from the opposite side was made at an angle of $30^{\circ}$. Similarly, the rootstock was beheaded at $15 \mathrm{~cm}$ from the collar region and a downward cut of $3 \mathrm{~cm}$ was made from the side of the rootstock ( $1 / 3^{\text {rd }}$ of the diameter of rootstock). 
Another single, slightly downward and inward cut was given on the rootstock at $0.5 \mathrm{~cm}$ above the lower end of the cut to remove the flip of the rootstock. The side view of the cut surface looks like the English letter ' $\mathrm{V}$ '. After that, the scion was gently placed on the cut surface of the rootstock so as to fit their cambium layer properly. The joint surface was tightly tied with grafting tape covering some portion of the above and below part of the union. Additionally, the upper cut surface of the scion was covered by parafilm tape to avoid desiccation. Intercultural operations such as irrigation, weeding, desuckering, manuring and plant protection activities were carried out regularly. The grafting tape was removed carefully after 120 days of grafting.

\section{Data collection and analysis}

The phenological and meteorological data were recorded regularly during the entire period of the research. The data regarding graft success, mortality, sapling height, number of leaves per sapling, leaf area, number of primary branches and number of secondary branches per sapling were recorded in every 30 days interval from 30 days after grafting to 150 days after grafting. The data were taken from randomly selected five sample plants for phenological parameters which were tagged at initial observation. The leaf area was measured by the graph paper method. Graft success and mortality were calculated by the following formulae:

\section{Graft success}

The emergence of shoot i.e. sprout from the terminal bud of scion was recorded in successful graft whereas unsprouted and dead scions were considered as failure ones.

Graft success $(\%)=\frac{\text { No of sprouted grafts }}{\text { Total number of grafts }} \times 100$ (Chalise et al., 2013a; Islam, 2013)

\section{Mortality}

All the sprouted scions may not survive, thus do not produce successful grafts. Death of sprouted grafts observed during the study was recorded as mortality percentage.

Mortality $(\%)=\frac{\text { Number of dead grafts after sprouting }}{\text { Total number of spouted grafts }} \times 100$ (Chalise et al., 2013)

The temperature and relative humidity of the screen house was recorded daily (four times in a day i.e. $6 \mathrm{am}, 12 \mathrm{pm}$, $6 \mathrm{pm}$ and $12 \mathrm{am}$ ) by digital thermohygrometer (RH/TEMP DATA LOGGER) and interpretation and analysis were made based on mean monthly temperature and relative humidity (Figure1 and Figure 2).

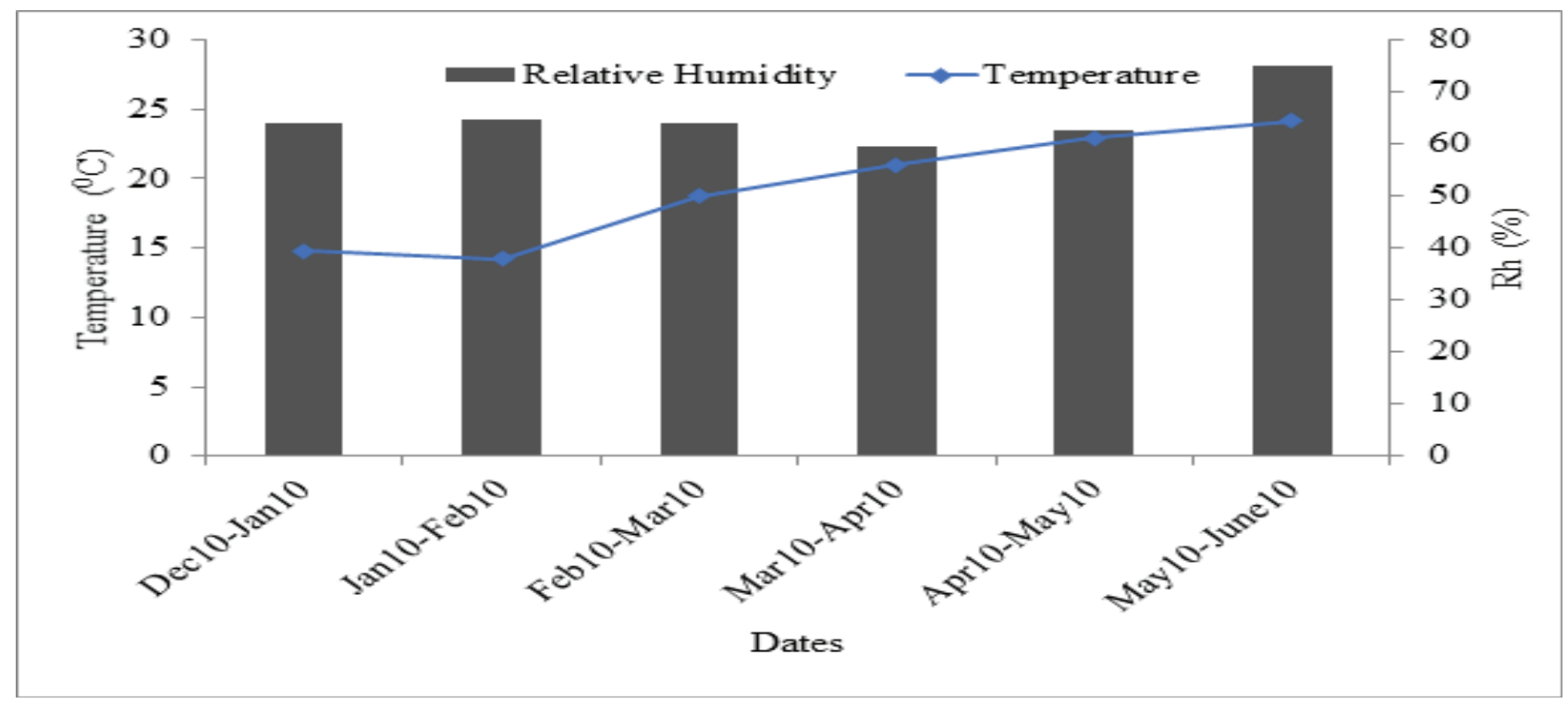

Figure 1: Mean monthly temperature and relative humidity of screen house for $10^{\text {th }}$ Decemberand $10^{\text {th }}$ January grafted sapling in Banepa, Kavre, 2017/18 


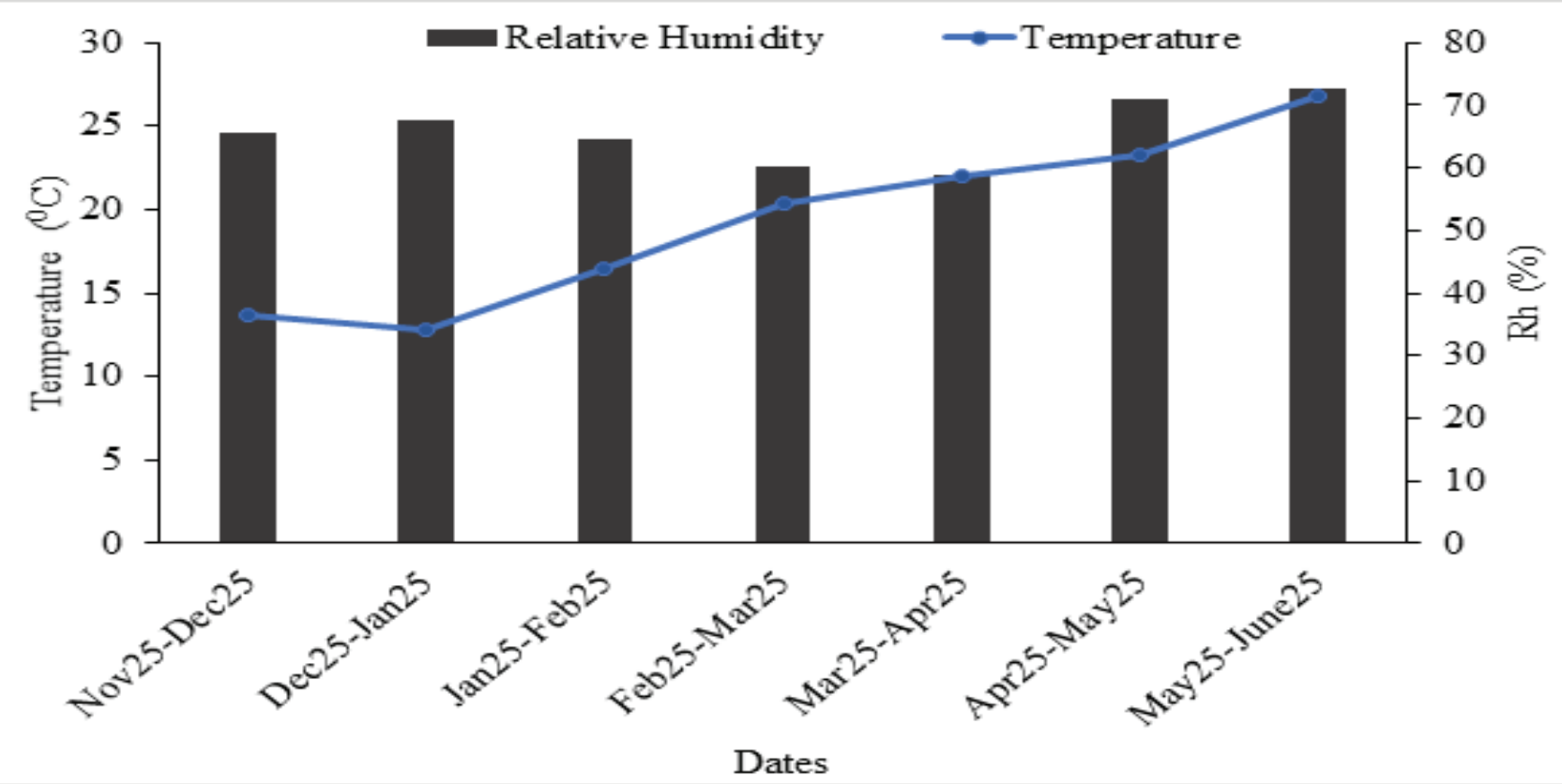

Figure 2: Mean monthly temperature and relative humidity of screen house for $25^{\text {th }}$ November, $25^{\text {th }}$ December and $25^{\text {th }}$ January grafted sapling in Banepa, Kavre, 2017/18

The data were entered into Microsoft Excel 2016 and analysis was carried out by using software R-Studio version 4.0.2. Both the descriptive [Mean, Coefficient of Variation (CV)] and inferential [Analysis of Variance (ANOVA), Standard Error of the Mean (SEm), Least Significance Difference (LSD)] analysis were carried out. Interpretations were made based on results, which were assisted by qualitative and quantitative data/ information available from both primary and secondary sources.

\section{Results}

\section{Graft success}

The effect of grafting dates on graft success of kumquat was found significant from 30-150 days after grafting
(Table 1). The graft success percent was same for the grafts prepared on $25^{\text {th }}$ November $(45.83 \pm 8.34 \%)$, $10^{\text {th }}$ January $(45.83 \pm 4.16 \%)$ and $25^{\text {th }}$ January $(45.83 \pm 8.34 \%)$ which was statistically higher than the graft success observed on $10^{\text {th }}$ December $(4.16 \pm 4.16 \%)$ grafted sapling at 30 days after grafting. The sprouting of scion was continuing in succeeding observation and in some cases, late sprouting was also observed and the sprouting was completed in 120 days after grafting for all grafting dates. $100 \%$ graft success was reported on $10^{\text {th }}$ and $25^{\text {th }}$ January grafted sapling which was statistically at par with grafting carried out on $25^{\text {th }}$ November and $25^{\text {th }}$ December while the lowest graft success percent was observed in the grafts prepared on $10^{\text {th }}$ December (70.83 $\pm 8.34 \%)$ at 150 days after grafting.

Table 1: Effect of grafting dates on graft success of kumquat in Banepa, Kavre, 2017/18

\begin{tabular}{|l|l|l|l|l|l|}
\hline \multicolumn{6}{|c|}{ Sprouted scion (\%) } \\
\hline \multicolumn{7}{|c|}{ 30 DAG } & \multicolumn{1}{|c|}{ 60 DAG } & 90 DAG & 120 DAG & 150 DAG \\
\hline Dates & \multicolumn{7}{|c|}{} \\
\hline Nov 25 & $45.83 \pm 8.34^{\mathrm{a}}$ & $70.83 \pm 4.16^{\mathrm{a}}$ & $87.5 \pm 0.00^{\mathrm{b}}$ & $91.66 \pm 4.16^{\mathrm{a}}$ & $91.66 \pm 4.16^{\mathrm{a}}$ \\
\hline Dec 10 & $4.16 \pm 4.16^{\mathrm{b}}$ & $41.66 \pm 4.16^{\mathrm{c}}$ & $66.66 \pm 4.16^{\mathrm{c}}$ & $70.83 \pm 8.34^{\mathrm{b}}$ & $70.83 \pm 8.34^{\mathrm{b}}$ \\
\hline Dec 25 & $37.50 \pm 0.00^{\mathrm{a}}$ & $45.83 \pm 4.16^{\mathrm{bc}}$ & $91.66 \pm 4.16^{\mathrm{ab}}$ & $91.66 \pm 4.16^{\mathrm{a}}$ & $91.66 \pm 4.16^{\mathrm{a}}$ \\
\hline Jan 10 & $45.83 \pm 4.16^{\mathrm{a}}$ & $58.33 \pm 4.16^{\mathrm{ab}}$ & $100 \pm 0.00^{\mathrm{a}}$ & $100 \pm 0.00^{\mathrm{a}}$ & $100 \pm 0.00^{\mathrm{a}}$ \\
\hline
\end{tabular}




\begin{tabular}{|l|l|l|l|l|l|}
\hline \multicolumn{7}{|c|}{ Sprouted scion (\%) } \\
\hline & \multicolumn{1}{|c|}{ 30 DAG } & \multicolumn{1}{|c|}{ 60 DAG } & \multicolumn{1}{c|}{ 90 DAG } & \multicolumn{1}{|c|}{ 120 DAG } & \multicolumn{1}{c|}{ 150 DAG } \\
\hline Jan 25 & $45.83 \pm 8.34^{\mathrm{a}}$ & $70.83 \pm 4.16^{\mathrm{a}}$ & $100 \pm 0.00^{\mathrm{a}}$ & $100 \pm 0.00^{\mathrm{a}}$ & $100 \pm 0.00^{\mathrm{a}}$ \\
\hline LSD & $19.87^{* *}$ & $13.18^{* *}$ & $8.88^{* * *}$ & $15.39^{*}$ & $15.39^{*}$ \\
\hline SEm $( \pm)$ & 5.00 & 4.16 & 1.66 & 3.33 & 3.33 \\
\hline CV & 30.02 & 12.41 & 5.39 & 9.17 & 9.17 \\
\hline Mean & 35.83 & 57.5 & 89.16 & 90.83 & 90.83 \\
\hline
\end{tabular}

$\mathrm{DAG}=$ Days after grafting, $\mathrm{CV}=$ Coefficient of variation, $\mathrm{LSD}=$ Least significant difference, $\mathrm{SEm}( \pm)=\operatorname{Standard}$ error of mean difference, Means followed by common letter (s) within a column are not significantly different at 5\% by DMRT, Significance codes $* * *$ at $0.001, * *$ at $0.01, *$ at $0.05, \mathrm{~ns}=$ non-significant

\section{Mortality of sprouted grafts}

The highest mortality was observed in the grafts prepared on $25^{\text {th }}$ November $(13.68 \pm 0.58 \%)$ while the lowest mortality was observed in the grafts prepared on $10^{\text {th }}$ December $(4.76 \pm 4.76 \%)$. There was no mortality of sprouted grafts was observed on $25^{\text {th }}$ December and $10^{\text {th }}$ January grafted sapling (Figure 3 ).

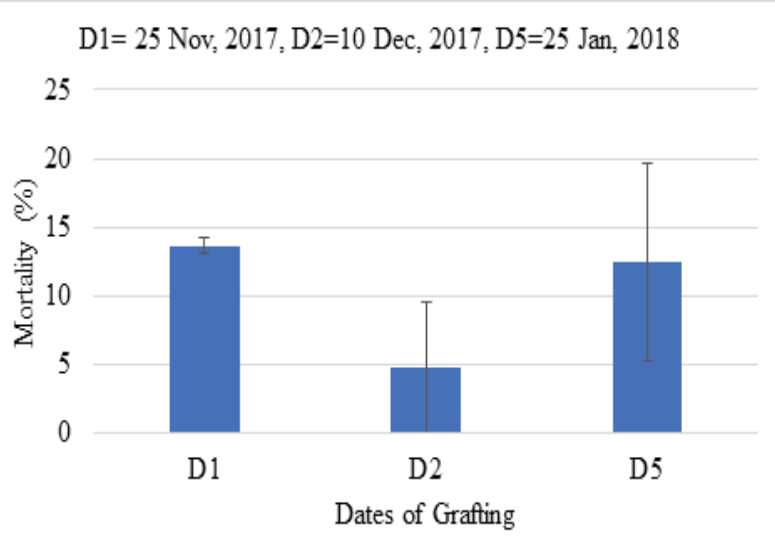

Figure 3: Mortality percentage of kumquat grafts at different grafting dates in Banepa,Kavre, 2017/18

\section{Sapling height}

The effect of grafting dates on sapling height was found significant at 150 days after grafting (Table 2). The highest sapling height was observed on $10^{\text {th }}$ January $(39.68 \pm 3.68 \mathrm{~cm})$ grafted sapling which was statistically at par with $25^{\text {th }}$ January and $25^{\text {th }}$ November grafted sapling. The lowest sapling height was observed on $25^{\text {th }}$
December $(29.20 \pm 0.50 \mathrm{~cm})$ grafted sapling which was statistically at par with $10^{\text {th }}$ December grafted sapling.

\section{Number of leaves per sapling and leaf area}

The effect of grafting dates on number of leaves per sapling and leaf area was found significant at 150 days after grafting (Table 2). The highest number of leaves per sapling was recorded on $10^{\text {th }}$ January $(23.12 \pm 3.43)$ grafted sapling which was similar to $25^{\text {th }}$ January and $25^{\text {th }}$ November grafted sapling. The lowest number of leaves per sapling was observed on $25^{\text {th }}$ December $(15.56 \pm 0.88)$ grafted sapling which was at par with $10^{\text {th }}$ December grafted sapling. Similarly, the leaf area was also observed maximum on $10^{\text {th }}$ January $(16.34 \pm 1.05$ $\mathrm{cm}^{2}$ ) grafted sapling while the minimum leaf area was observed on $10^{\text {th }}$ December $\left(11.43 \pm 0.54 \mathrm{~cm}^{2}\right)$ grafted sapling.

\section{Number of primary and secondary branches per sapling}

The effect of grafting dates on the number of primary and secondary branches per sapling was found nonsignificant at 150 days after grafting (Table 2). The highest number of primary branches $(3.06 \pm 0.63)$ and secondary branches $(3.66 \pm 0.28)$ were reported on $10^{\text {th }}$ January grafted sapling while the lowest number of primary branches $(1.46 \pm 0.28)$ and secondary branches (1.46 \pm 0.93$)$ were recorded on $10^{\text {th }}$ December grafted sapling. 
Table 2: Effect of grafting dates on growth of different parameters of kumquat at 150 days after grafting in Banepa,Kavre, 2017/18

\begin{tabular}{|c|c|c|c|c|c|}
\hline & $\begin{array}{l}\text { Sapling height } \\
\text { (cm) }\end{array}$ & Leaf number & Leaf area $\left(\mathrm{cm}^{2}\right)$ & $\begin{array}{l}\text { Primary } \\
\text { branches }\end{array}$ & $\begin{array}{r}\text { Secondary } \\
\text { branches }\end{array}$ \\
\hline Nov 25 & $36.04 \pm 1.46 \mathrm{ab}$ & $19.62 \pm 1.63 \mathrm{ab}$ & $13.99 \pm 0.85 \mathrm{abc}$ & $2.33 \pm 0.53 \mathrm{ab}$ & $3.00 \pm 0.19 \mathrm{ab}$ \\
\hline Dec 10 & $32.57 \pm 1.66 b c$ & $17.05 \pm 1.00 \mathrm{bc}$ & $11.43 \pm 0.54 \mathrm{c}$ & $1.46 \pm 0.28 b$ & $1.46 \pm 0.93 b$ \\
\hline Dec 25 & $29.20 \pm 0.50 \mathrm{c}$ & $15.56 \pm 0.88 \mathrm{c}$ & $12.37 \pm 0.07 \mathrm{bc}$ & $2.53 \pm 0.13 \mathrm{ab}$ & $3.33 \pm 0.35 \mathrm{a}$ \\
\hline Jan 10 & $39.68 \pm 3.68 \mathrm{a}$ & $23.12 \pm 3.43 \mathrm{a}$ & $16.34 \pm 1.05 \mathrm{a}$ & $3.06 \pm 0.63 \mathrm{a}$ & $3.66 \pm 0.28 \mathrm{a}$ \\
\hline Jan 25 & $36.56 \pm 0.59 \mathrm{ab}$ & $20.02 \pm 0.75 \mathrm{ab}$ & $14.36 \pm 1.13 \mathrm{ab}$ & $2.46 \pm 0.06 \mathrm{ab}$ & $3.40 \pm 0.50 \mathrm{a}$ \\
\hline LSD & $5.53^{*}$ & $3.92 *$ & $2.78^{*}$ & $1.19 \mathrm{~ns}$ & $1.63 \mathrm{~ns}$ \\
\hline $\operatorname{SEm}( \pm)$ & 1.57 & 1.53 & 0.72 & 0.32 & 0.45 \\
\hline $\mathrm{CV}$ & 8.60 & 11.12 & 10.99 & 27.19 & 29.83 \\
\hline Mean & 34.81 & 19.07 & 13.70 & 2.37 & 2.97 \\
\hline
\end{tabular}

$\mathrm{DAG}=$ Days after grafting, $\mathrm{CV}=$ Coefficient of variation, $\mathrm{LSD}=$ Least significant difference, $\operatorname{SEm}( \pm)=$ Standard error of mean difference, Means followed by common letter (s) within a column are not significantly different at 5\% by DMRT, Significance codes ***at $0.001, * *$ at $0.01, *$ at $0.05, \mathrm{~ns}=$ non-significant

\section{Discussion}

\section{Graft success}

The variation in the graft success percent might be due to variation of temperature and relative humidity during different months. The graft successis directly related to prevailing temperature and relative humidity at the time of graft union formation. The early callus formation and initiation of subsequent growth are promoted by congenial weather conditions especially temperature and relative humidity of propagating structure (Chander et al., 2016). The highest graft success of the grafts prepared in January might be due to optimum temperature at the time of graft union formation. Meteorological data of screen house showed that the grafts prepared in January exposed to high temperature and slightly higher relative humidity as compared to previous dates (Figure $1 \&$ Figure 2). In addition to this, a very low amount of GA within the scion taken in the severe winter might be another reason for lower sprouting on early dates. The present result was supported by Chalise et al. (2013) and Gautam et al. (2001), as they reported maximum graft success in

January on mandarin orange at Paripatle, Dhankuta and Lumle, Kaski respectively.

Correlation analysis was done to study the effect of temperature and relative humidity on graft success percent. The analysis showed that the correlation between temperature and graft success was significant and positive for the last three grafting dates $\left(25^{\text {th }}\right.$ December, $10^{\text {th }}$ January and $25^{\text {th }}$ January) while relative humidity did not show significant relation with graft success in any dates. However, the analysis showed that relative humidity had also little and weak positive association with graft success in the last two grafting dates i.e. $10^{\text {th }}$ January and $25^{\text {th }}$ January while the graft success of the first three grafting dates showed a negative association with relative humidity. This might be one of the main reasons for the highest graft success in January grafted sapling compared to early dates (Table3). 
Table 3: Correlation coefficient between grafting dates and graft success of kumquat in Banepa, Kavre, 2017/2018

\begin{tabular}{|l|c|c|c|c|}
\hline \multirow{2}{*}{ Dates of grafting } & \multicolumn{2}{|c|}{ Pearson correlation value } & \multicolumn{2}{c|}{ P value } \\
\cline { 2 - 5 } & Temperature & Relative humidity & Temperature & Relative humidity \\
\hline $25^{\text {th }}$ November, 2017 & 0.770 & -0.678 & $0.127 \mathrm{~ns}$ & $0.208 \mathrm{~ns}$ \\
\hline $10^{\text {th }}$ December, 2017 & 0.809 & -0.542 & $0.097 \mathrm{~ns}$ & $0.345 \mathrm{~ns}$ \\
\hline $25^{\text {th }}$ December, 2017 & 0.951 & -0.305 & $0.012^{*}$ & $0.617 \mathrm{~ns}$ \\
\hline $10^{\text {th }}$ January, 2018 & 0.925 & 0.122 & $0.024^{*}$ & $0.844 \mathrm{~ns}$ \\
\hline $25^{\text {th }}$ January, 2018 & 0.884 & 0.333 & $0.046^{*}$ & $0.583 \mathrm{~ns}$ \\
\hline
\end{tabular}

$*$ refers to significant at 0.05 and $* *$ refers to significant at 0.01 , ns refers to non-significant

\section{Mortality of sprouted grafts}

The highest mortality percent of sprouted graft prepared on $25^{\text {th }}$ November might be due to a lack of moisture needed to meet transpiration loss from newly expanded leaves due to a rapid increase in temperature from 60 days after grafting (Figure 2). The optimum level of temperature and relative humidity for callusing and differentiation of callus cells to xylem and phloem ensured the better movement of water and nutrient towards leaves and photosynthate away from leaves which might result zero mortality on $10^{\text {th }}$ January and $25^{\text {th }}$ December grafted sapling. The mortality of sprouted grafts was higher in the present study as compared to the study carried out by (Chalise et al., 2013) which might be due to differences in species undertaken, physiological conditions of scion and rootstock and prevailing environmental conditions.

\section{Height of sapling}

The height of sapling is greatly influenced by different growth parameters such as the number of leaves per sapling, leaf area and number of primary and secondary branches. The faster healing of graft and subsequent production and translocation of photosynthate, growth regulators, nutrients and water determine the ultimate growth of grafted sapling (Hartmann et al., 2011; Chalise et al., 2013; Melnyk et al., 2015). The greater the number of leaves and leaf area, higher is the photosynthetic activity and ultimately better growth and development of grafts. Additionally, the number of leaves increases with an increased number of primary and secondary branches which ultimately resulted the higher sapling height (Hartmann et al., 2002). Similarly, auxin is transported basipetally from leaves and buds and promotes the vascular regeneration across the graft junction, as it involves in wound response (Mazur et al., 2016; Melnyk et al., 2015; Matsuoka et al., 2016). Multiple regression analysis also showed that there was a statistically significant and positive relationship between sapling height and number of leaves per sapling (Table 4). The model showed that $86 \%$ of the variation of sapling height can be explained by the number of leaves per sapling and leaf area. Being taken leaf area constant, sapling height will increase by $0.97 \%$ if the number of leaves per sapling will increase by $1 \%$. The highest sapling height of $10^{\text {th }}$ January grafted sapling might be due to the production of a greater number of leaves resulted from favorable environmental conditions from the graft union formation to the growth stage. The present result was in agreement with Chalise et al. (2013) in mandarin and Adhikari (2006) in acid lime.

\section{Number of leaves per sapling and leaf area}

The highest number of leaves per sapling and maximum leaf area of $10^{\text {th }}$ January grafted sapling might be due to early bud breaking resulting from early healing and graft union formation due to favorable temperature and relative humidity. Early healing of graft wound between scion and rootstock promotes the early and easy availability of raw material for photosynthesis which ultimately increased the growth of the whole plant. The lower number of leaves and leaf area in early grafted sapling might be due to low temperature at the time of graft union formation and leaves emergence and development. The present result was inconsistent with Adhikari (2006) in the acid lime sapling. 


\section{Number of primary and secondary branches per} sapling

The number of primary branches and secondary branches and growth of grafted sapling primarily depends upon the availability of photosynthate, phytohormone and nutrients. A higher number of leaves per sapling and greater leaf area accumulate more photosynthate which directly contributed to the growth of sapling. The growth of sapling is correlated with the production of the number of primary and secondary branches. This might be the reason for the superiority of primary and secondary branches on $10^{\text {th }}$ January grafted sapling. The present result was supported by Adhikari (2006) who reported the highest number of primary branches per sapling in acid lime grafted on $16^{\text {th }}$ January. Dubey and Singh (2003) and Seletsu et al., (2011) also reported a variation of the number of branches in different citrus species.

Table 4: Multiple linear regression equation showing the response of number of leaves per sapling and leaf area on sapling height of kumquat in Banepa,Kavre, 2017/18

\begin{tabular}{|l|l|l|}
\hline \multicolumn{1}{|c|}{ Predictors } & \multicolumn{1}{c|}{ Regression coefficient } & \multicolumn{1}{c|}{ P value } \\
\hline Number of leaves/sapling (LN) & 0.97 & $0.00^{* *}$ \\
\hline Leaf area (LA) & 0.45 & $0.19 \mathrm{~ns}$ \\
\hline Intercept & 9.91 & \\
\hline Prediction equation & \multicolumn{2}{|l|}{ Sapling height $=9.91+0.97 \mathrm{LN}+0.45 \mathrm{LA}$} \\
\hline Model F & $44.49^{* *}$ & \\
\hline Adjusted R square & 0.86 & \\
\hline Standard error & 1.74 & \\
\hline
\end{tabular}

$*$ refers to significant at 0.05 and $* *$ refers to significant at 0.01 , ns refers to non-significant

\section{Conclusion}

In conclusion, based on the findings of the experiment, $10^{\text {th }}$ January was the most suitable time for the grafting of kumquat in the central mid-hills of Nepal. In spite of having high potentiality and high economic and nutritional value, up to the present, kumquat is considered as a minor fruit crop in Nepal. The commercial propagation and multiplication techniques of the kumquat need to be further explored in different parts of the country. A multi-location trial at different agro-climatic conditions is recommended to identify a suitable grafting date for Kumquat to produce good quality sapling.

\section{Acknowledgments}

The authors would like to acknowledge ECARDSNepal for providing research materials (scion and rootstock) and propagating structure (screen house). We also acknowledge Tribhuvan University, Institute of Agriculture and Animal Science, PG Program for providing grafting tools like secateur, grafting knife and parafilm tape.

\section{Declaration of conflict of interest and ethical} approval:

$\mathrm{N}$. Bhandari was involved in designing the experiment, conducting the grafting, data recording and writing the manuscript. C. Regmi was involved in designing the experiment and participated in writing the manuscript. All the authors have read the manuscript before submitting to the journal Page 3 of 3 Nepalese Horticulture and declare that there is no any type of competing interest regarding the current manuscript. The current article does not include any human participants or animals by the authors and has taken prior approval if applicable.

\section{References}

Adhikari, A. (2006). Effect of grafting season on success and growth of acid lime (Citrus aurantifolia Swingle) in Rampur, Chitwan [Unpublished master thesis]. Tribhuvan University, IAAS, Rampur, Chitwan, Nepal.

Chalise. B., Baral, D.R., Gautam, D.M., \& Thapa. R.B. (2013). Effect of Grafting Dates and Methods on Success and Growth of Mandarin (Citrus reticulata Blanco) Sapling. Nepal Journal of 
Science and Technology, 14(1), 23-30. DOI: https://doi.org/10.3126/njst.v14i1.8873

Chander, S., Kumari, S., Nimbolkar, P.K., \& Bora, L. (2016). Seasonal Variability and Environmental Condition to Grafting Success in Fruit Crops-A Review. Advances in Life Sciences, 5(16), 58125816.

Dubey, A.K., \& Singh, A.K. (2003). Evaluation of rootstocks of different mandarin (Citrus reticulata) under foot-hills conditions of Arunchal Pradesh. Indian Journal of Agricultural Science, 73(10), 527-529.

Gautam, I.P., Sah, D.N., \& Khatri, B. (2001). Effect of time of grafting and budding on trifoliate rootstocks for appropriate mandarin orange sapling production. Lumle Working Paper No. 2001/20. Lumle Agricultural Research Station, Lumle, Kaski, Nepal.

Gmitter, F.G., Soneji, J., Rao, M.N., \& Huang, S. (2007). Eds. Janick, J. and R.E. Paull. The Encyclopedia of Fruit and Nuts. 773-784.

Hartmann, H.T., Kester, D.E., Davies, F.T., \& Geneve, R.L. (2002). Hartmann and Kester's plant propagation: Principles and practices, $7^{\text {th }}$ ed. Prentice Hall Upper Saddle River.

Hartmann, H.T., Kester, D.E., Davies, F.T., \& Geneve, R.L. (2011). Hartmann and Kester's Plant Propagation: Principles and Practices, $8^{\text {th }}$ ed. Prentice Hall, New Jersey.

Hussein, J.H., \& Ibrahim, D.A. (2020). The Response of In Vitro Propagation of Marumi Kumquat (Fortunella Japonica Thunb.) to Different Culture Media, Plant Growth Regulators and Different Fructose Concentration. Journal of Duhok University, 23(1), 178-190.

Matsuoka, K., Sugawara, E., Aoki, R., Takuma, K., Terao-Morita, M., Satoh, S., \& Asahina, M. (2016). Differential cellular control by cotyledon-derived phytohormones involved in graft reunion of Arabidopsis hypocotyls. Plant and Cell Physiology, 57(12), 2620-2631. DOI: https://doi.org/10.1093/pcp/pcw177

Mazur, E., Benkova, E., \& Friml. J. (2016). Vascular cambium regeneration and vessel formation in wounded inflorescence stems of Arabidopsis. Scientific reports, 6 (1), 1-15. DOI:

\section{https://doi.org/10.1038/srep33754}

Melnyk, C.W., Schuster, C., Leyser, O., \& Meyerowitz, E.M. (2015). A developmental framework for graft formation and vascular reconnection in Arabidopsis thaliana. Current Biology, 25(10), 1306-1318. DOI:https://doi.org/10.1016/j. cub.2015.03.032

Morton, J. F. (1987). Fruits of warm climates. JF Morton.

Nouri, A., \& Shafaghatlonbar, A. (2016). Chemical constituents and antioxidant activity of essential oil and organic extract from the peel and kernel parts of Citrus japonica Thunb.(kumquat) from Iran. Natural product research, 30(9), 10931097.

Palma, A., \& D'Aquino, S. (2018). KumquatFortunella japonica. In Exotic Fruits (pp. 271278). Academic Press.

Poon, T.B. (1999). Effect of grafting methods and time on mandarin sapling production at Dailekh. Proceedings of the $2^{\text {nd }}$ National Horticultural Research Workshop, Khumaltar, Lalitpur, May 13-15, 1998. p.65-68.

Islam, R. (2013). Effect of scion diameter on the grafting success, survivability and growth of different mango varieties (Unpublished master thesis). Bangladesh Agricultural University.

Satyal, P., Paudel, P., Limbu, K., \& Setzer, W. N. (2012). Leaf essential oil composition of Citrus japonica from Nepal. Journal of Essential Oil Bearing Plants, 15(3), 357-359. DOI: https://doi.org/10 $.1080 / 0972060 X .2012 .10644059$

Seletsu. S., Paul, P.K., \& Thangjam, K. (2011). Effect of time and species on bud union and survivability in citrus under Allahbad condition. Journal of Crop and Weed, 7(1), 89-93.

Singh, S., \& Singh, A. (2006). Standardization of method and time of propagation in jamun (Syzygium cumini) under semi arid environment of Western India. The Indian Journal of Agricultural Sciences, 76(4), 242-245. 